\title{
Infrarenal Aortic Segment
}

National Cancer Institute

\section{Source}

National Cancer Institute. Infrarenal Aortic Segment. NCI Thesaurus. Code C116179.

The portion of the abdominal aorta that lies below the kidneys. 